„Ante Portas - Studia nad Bezpieczeństwem”

2018, $\operatorname{Nr} 2(11)$

DOI: $10.33674 / 2201811$

\begin{abstract}
Alika GUCHUA ${ }^{1}$
Georgia
\end{abstract}

\title{
ASYMMETRICAL THREATS AND THE IMPACT OF HYBRID WAR ON GLOBAL SECURITY AND ROLE OF NATO IN ENSURING PEACE
}

\begin{abstract}
:
The article deals with new type of asymmetric warfare and hybrid war. The potential threats in international politics and global security issues, Euro-Atlantic Alliance policy of fighting against terrorism. A serious challenge to modern security creates many problems around the world. The beginning of the twenty-first century was marked by proliferation of hybrid wars, held between flexible and sophisticated adversaries engaged in asymmetric conflicts using various forms. The hybrid war is caused by a hybrid threat, a blend of military and non-military assets and operations, terrorism, guerrilla tactics, criminality and cyber attacks. The use of hybrid type tactics can ensure the achievement of the main objectives of an international actor, with a minimum of effort, usually without using the force, and can deny to the target/victim the possibility to take any defensive actions. The complexity, diversity, the nature and dynamics of contemporary conflicts represent challenges that should be widely studied. The war, be it ancient or modern, hybrid or not, is always complex and cannot be described by a single adjective. The work focuses on the role of NATO in ensuring peace worldwide in the context of new asymmetric threats. The aim of the research topic: analyzing global challenges, which pose a serious threat to international security.
\end{abstract}

\section{Keywords:}

Asymmetric threats, Hybrid war, Hybrid conflict, Russia-Ukraine, NATO, Aggression, Security, Armed conflict, International Actors

\footnotetext{
${ }^{1}$ Alika Guchua is a scientific researcher, Caucasus International University. Email: alikaguchua7@gmail.com
} 


\section{Asymmetric threats}

Against the challenges and geopolitical processes in the modern period world, research of the challenges coming from asymmetrical threats and hybrid warfare is very important. The world faces a number of challenges that cannot be solved without a united effort. Therefore, it becomes necessary to create alliances and enhance the effectiveness of international organizations. Coming from the current situation of today's reality and geopolitical changes the role and the function of NATO is very important in world security issues. Since the establishment of the North Atlantic Alliance, ensuring collective defence and security is one of the main principles and purposes of functioning of this organization that require the Alliance to prevent the land, air and naval attacks with united forces, however, in modern times the Alliance faced new challenges that come from asymmetric threats and hybrid warfare.

The security trends play the great role in the process of forming a new system of international relations. In the past few years, one can often hear the reasoning that the nature of war in the twenty-first century has changed. Non-state structures even a century ago used partisan methods of warfare, and the beginning of the twentieth century was marked by the use of terrorist tactics.

Before we begin to talk about asymmetric threats and a hybrid war, it is important to consider what these two phenomena mean and what role they play in global security. During the consideration of the hybrid war, it is interesting to pay attention to the asymmetric warfare factor - asymmetric war represents such a war when the military powers of the opposing sides clearly differ from each other. The military tactics or the strategy used by them are very different from each other.

The term asymmetric warfare is used when describing situations such as guerrilla warfare, terrorism, insurrection and during such armed conflicts when regular military force confronts an irregular, ill-armed opponent.

The term became popular in 1975, when Andrew J. R. Mack, wrote in academic journal World Politics, "Why Big Nations Lose Small Wars," where he used an asymmetric war to determine the differences between important military forces among the parties involved. In the word "power" he meant the material strength, like a large army, good weapons, a developed economy, etc.

As for the connection of the asymmetric war with terrorism, there are different opinions on this issue. In today's world, asymmetric warfare is being increasingly considered as a part of the fourth generation war. Some believe that if the asymmetric war goes beyond the rules of war, it turns into terrorism. In addition, some believe that the asymmetric war is not connected with terrorism. They believe, because of the propaganda of the strong parties, it identifies 
the weaker party as bandits or terrorists. They also believe that the word terrorism is specifically used for political purposes because of its negative significance. One of the main security problems of the modern world is asymmetrical threats, such as international terrorism and transnational organized crime; Weapons, including weapons of mass destruction and its components; Also illegal drugs and drug trafficking; Human trafficking, cybercrime, and the fourth generation war. There are many other types of confrontations - rebellion, civil war, revolution, etc.

The tactical success of asymmetric wars depends on several components. On the example of technological advantage - if any party has a technological advantage, this can outweigh the enemy's numerical advantage. Neutrality of technological advantage is possible on important enemy facilities and with an attack on infrastructure. With attacking the electrical power lines or generators, roads, pipelines or water. In heavily populated places, such sabotage can greatly affect the morale and economics of people inhabiting the territories. The weaker side in such a war uses special tactics to cope with a strong opponent. You can break the rules of war and use them for your own good. The rules of war prohibits the use of a medical machine for asylum, an attack or an ambush, and the use of urban settlement for military bases is also prohibited. The weaker side uses such tactics with the hope that the opposing party will defend the rules of war and not attack the city ${ }^{2}$.

The beginning of the $21^{\text {st }}$ century brought about non-conventional security threats (they include natural disasters, drug, weapon and human trafficking, cyber warfare and piracy, etc.) which represent new challenges for those international organizations that consider maintenance of security and stability as their principal goal on either global or regional levels. The North-Atlantic Alliance has taken the responsibility for addressing these new challenges ${ }^{3}$.

Today NATO provides its capabilities and resources to assist international and regional organizations in tackling crises and resolving a wide range of problems.

Asymmetric warfare used to be determined as "a conflict including two states with different total military and economic resources". However after 9/11 attacks the definition has been adjusted, Asymmetric warfare is now defined as

\footnotetext{
${ }^{2}$ G. Maghradze, V. Maisaia, 21st Century International Policy and Theory of Cooperative Security: Myth and Reality - Regional and Global Aspects, Tbilisi 2017, pp. 25-26.

${ }^{3}$ Strategic Concept For the Defence and Security of The Members of the North Atlantic Treaty Organization, 2011, <http://www.nato.int/lisbon2010/strategic-concept-2010eng.pdf> (30.06.2018).
} 
"using inferior tactical or operational strength against the vulnerabilities of superior opponent to achieve the disproportionate effect with the aim of undermining [the opponent's] will in order to achieve the asymmetric actor's strategic objectives." 4

The problem of terrorism is not only the problem of a single country but also the first enemy of international security. The terrorist attacks of September $11,2001(9 / 11)$ led to a more clear perception of the threat of terrorism. Terrorism has become the most acute issue after this incident, and maintains the considerable attention of the international community until now.

After 9/11 terrorist attack, NATO instantly expressed support for U.S. For the first time NATO activated the Article 5, which envisaged the collective protection of member states at risk. The purpose of this action was not only America fighting against terrorism. Europe joined the events of 9/11. The fight against terrorism became the mainstay of EU member states.

While we start talking about the factor of hybrid war in the modern era, let us see what the existing theories and their authors are saying about the hybrid war. In general, there are two basic mental approaches around the hybrid war. Some researchers think that a "hybrid war" is a reality that needs to be understood. They think that this is separate from the traditional and non-traditional possibilities of creating a war, although it includes both. According to the second part of the researchers, the "hybrid war" by its content consists of the fact that it is not new for the stories of creating a war, does not need branches and is easily described with the help of comprehension of the historical perspective. In general, it can be said that the vast majority of researchers agree that in the form of creating a modern war, there are novices that need attention. The main question is how new this phenomenon is in the framework of the historical perspective.

At present, the term "hybrid war" has a significant place in the political dictionary. Over the past decade, a new military strategy has become more relevant in the world political arena.

In the Euro-Atlantic space, the number of conflicts that are not part of the Western category of war is growing. We can say that the analysis of these conflicts show the modern idea of a hybrid war, in which we see an intentional combination of forms of war to achieve strategic goals.

Modern American military analyst of conflicts, Frank Hoffman in various forms of analysis of hybrid threats defines as follows: "hybrid threats if the enemy at the same time uses conventional weapons, irregular tactics of terror-

\footnotetext{
${ }^{4}$ W. H. von Heinegg, Asymmetric Warfare: How to Respond?, "International Law Studies", volume 87, p. 464.
} 
ism and criminal behavior, as well as a combination of military operations to achieve political goals." ${ }^{5}$

Military experts of the United States during the XX century introduced the concept of military planning together with the concept of "hybrid threats" and, consequently, the new concept of "hybrid wars" - a form of warfare that includes different composition, means, and level of training and characteristic of forces - was created. However, what makes a hybrid challenge the new phenomenon is the growing importance of non-military means. This is a modern form of war, which focuses primarily on achieving strategic goals without physical confrontation, especially at the initial stage of the conflict.

Conventional (regular) warfare is, according to NATO's definition, warfare where regular opponents, officially enlisted as states, are engaged and regular tactics and activities are used, while respecting international treaties, conventions and laws.

Irregular warfare, according to available NATO's definitions, represents a warfare that denotes a form of conflict, where one or more protagonists adopt irregular methods. Additionally, "irregular troops are any combatants not formally enlisted in the armed forces of a nation-state or other legally constituted entity." Other definitions describe it as "a violent struggle among state and nonstate actors for legitimacy and influence over the relevant populations. Irregular warfare favours indirect and asymmetric approaches, though it may employ the full range of military and other capabilities, in order to erode an adversary's power, influence, and will. "Moreover, irregular opponents are unlikely to adhere to recognized treaties and international conventions. On the other hand, they are likely to rely on local support, fight in the place they live and they are often hard to distinguish from local civilians. The irregular opponents' tactic will often include undermining and eroding target's will and determination. The tactic also includes avoiding regular decisive deployment of national forces, and if necessary, then preferably under the terms and circumstances chosen by the irregular opponents.

Hybrid warfare in NATO's view is a violent conflict applying combination and simultaneous use of conventional and irregular warfare, involving both state and non-state actors, used adaptively in pursuit of their objectives and not limited to physical battlefield or territory. Each attack contains its own combinations and mutations of the two and targets further aspects of state and society to undermine it and reach its goals. Hybrid warfare can be employed in conflicts not only by states and armed forces but also by a variety of actors beyond

\footnotetext{
${ }^{5}$ F. G. Hoffman, Hybrid Warfare and Challenges, “Joint Force Quarterly”, Issue 52, 2009, p. 34.
} 
the authority of states. (Such as terrorist or extremist groups.) Even though the phenomenon is hardly new, what is new and surprising is the "scale of use and exploitation of old tools in new ways."

\section{Figure 1: Hybrid Threats}

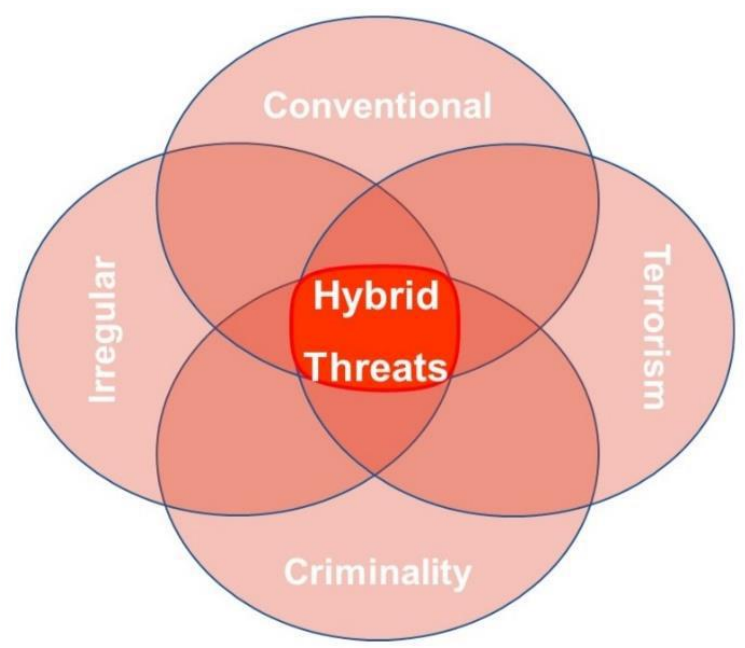

Source: NATO Hybrid Threats. Background Report, Prague 2015, p. 5.

Hybrid methods of warfare, such as propaganda, deception, sabotage and other non-military tactics have long been used to destabilize adversaries. What is new about attacks seen in recent years is their speed, scale and intensity, facilitated by rapid technological change and global interconnectivity. NATO has a strategy on its role in countering hybrid warfare and stands ready to defend the Alliance and all Allies against any threat, whether conventional or hybrid.

\section{Highlights}

- The primary responsibility to respond to hybrid threats or attacks rests with the targeted nation.

- NATO is prepared to assist any Ally against hybrid threats as part of collective defense. The Alliance has developed a strategy on its role in countering hybrid warfare to help address these threats.

${ }^{6}$ NATO Hybrid Threats. Background Report, Prague 2015, pp. 4-5. 
- In July 2018, NATO leaders agreed to set up counter-hybrid support teams, which provide tailored targeted assistance to Allies upon their request, in preparing for and responding to hybrid activities.

- NATO is strengthening its coordination with partners, including the European Union, in efforts to counter hybrid threats.

- NATO's Joint Intelligence and Security Division has a hybrid analysis branch, that helps improve situational awareness.

- It also actively counters propaganda - not with more propaganda, but with facts - online, on air and in print ${ }^{7}$.

Hybrid threats include cyber-attacks, disinformation, economic pressure, the destruction of non-permanent armed forces and the use of regular forces, which is of military and non-military importance. The most important work of NATO is the prevention and destruction of hybrid attacks (the scale and frequency of which has greatly increased in recent years) and it does not matter whether it comes from government or non-state bodies. Hybrid methods first blur the boundary between peace and war and begin to be a problem for NATO. Since 2015, NATO has begun to fight with this warfare. To this end, NATO will prepare the Alliance and Allies to the extent that they can provide it all. For constant readiness, NATO continually gathers, exchanges and evaluates information to ensure any necessary activity. An integrated intelligence and security unit at NATO Headquarters assists this process. The hybrid analysis department provides maximum information on hybrid threats. Together with the abovementioned, NATO also supports allied in civic preparedness and response to chemical, biological, radiological and nuclear (CBRN) phenomena; protects critical infrastructure, strategic communications, and energy security, combats terrorism, and also provides cyber defense, which is very important. To implement all of the above, it is very important to conduct trainings and checks, which will make the fight against hybrid threats much effective.

NATO can hold up hybrid threats much faster and more agile, and each time it improves preparedness for the fight and the decision-making process and the management of defense and control. It also shows that the Alliance is also strong in political and military efficiency and in a quick decision-making process. In the event that the struggle becomes impracticable, NATO, with its speed and flexibility, at any time and in any place protects its allies from any attacks.

7 NATO's response to hybrid threats, <https://www.nato.int/cps/en/natohq/topics_156338.htm?selectedLocale=en> (30.06.2018). 
To strengthen and improve the fight against hybrid threats, NATO continues to cooperate with Finland, Sweden, Ukraine and the European Union. The European Union and NATO have especially strengthened their cooperation against cyber-attacks and are successfully conducting this process.

For better experience, centres of excellence (international research centres) provide the alliance with more knowledge at the national or multinational level.

In October 2017, NATO Secretary General Jens Stoltenberg, together with the European Union Representative for Foreign Affairs and Security Policy / Vice President of the European Commission Federica Mogherini, opened the European Centre of Excellence for Combating Hybrid Threats in Finland, which supports 14 countries to improve their capabilities and preparedness to counter hybrid threats ${ }^{8}$.

Together with this centre, others also support NATO in countering hybrid threats, including the Strategic Communications Excellence Centre in Riga, Latvia; Centre of Excellence for Joint Cyber War in Tallinn, Estonia; and a Centre For Enhancing Energy Security in Vilnius, Lithuania, which is a big enough support for NATO and all other alliances.

\section{New Security Challenges: \\ The Emergence of 'Hybrid Threats' as Challenges to Peace and Security}

Multimodal, low intensity, kinetic as well as non-kinetic threats to international peace and security, including cyber war, asymmetric conflict scenarios, global terrorism, piracy, transnational organized crime, demographic challenges, resource security, retrenchment from globalization, and the proliferation of weapons of mass destruction were identified and labelled by NATO as 'Hybrid Threats', as threats 'posed by adversaries, with the ability to simultaneously employ conventional and non-conventional means adaptively in pursuit of their objectives'.

Having identified these threats, NATO undertook work on creating a comprehensive conceptual framework, a Capstone Concept, which was to provide a legal framework for identifying and categorizing such threats within the wider frame of possible multi-stakeholder responses. In 2011, NATO's Allied Command Transformation (ACT) supported by the U.S. Joint Forces Command Joint Irregular Warfare Centre (USJFCOM JIWC) and the U.S. National Defense University (NDU) conducted specialized workshops related to 'Assessing

8 Secretary General to visit the Republic of Finland, <https://www.nato.int/cps/en/natohq/news_147411.htm> (30.06.2018). 
Emerging Security Challenges in the Globalized Environment (Countering Hybrid Threats [CHT]) Experiment'.

These workshops took place in Brussels, Belgium, and Tallinn, Estonia, and aimed at identifying possible threats and discussing some key implications when countering such risks and challenges. The findings of the workshops were published in the ACT's final report and recommendations in 2011.

Hybrid threats faced by NATO and its non-military partners require a comprehensive approach allowing a wide spectrum of responses, be it kinetic and non-kinetic by military and non-military actors. Such a comprehensive response will have to be in partnership with other stakeholders, such as international and regional organizations as well as representatives of business and commerce. However, due to a lack of financial resources in general, and an absence of the political will to create necessary 'smart defence' capabilities among its member states, NATO decided in June 2012 to cease the work on CHT at its organizational level while encouraging its member states and associated NATO Excellence Centres to continue working on hybrid threats ${ }^{9}$.

At present, information warfare is the main component of the war, which means influencing the masses through access to the media, getting support for some idea and making the client's policy. Information warfare often includes informative, propagandistic, psychological, and cyber components and the characteristic of the "hybrid war" is the use of integrated financial resources, material resources and hidden military means.

A new type of war in the North Atlantic alliance, the "hybrid war" that unites all elements of a new strategy, is called tactics, when military facilities are not used. The war contains elements of propaganda and disinformation, as well as forced use of economic pressure and Special Forces. This kind of war is referred to as "soft power". Today, the main component of the war is "informational war", which means influencing the masses through access to the media, getting support for some idea and making a client's policy. "Informative war" often combines information-propaganda, psychological and cybercrime.

A vivid example of such a conflict is the Russian aggression against Ukraine. The appearance of Russian militaries in Crimea without the marking signs ("hidden faces, hidden management and controls") directly means the secretive use of Special Forces, which is one of the main elements of this kind of war. The use of such forces, which do not have any marks, in military opera-

\footnotetext{
${ }^{9}$ S. D. Bachmann, H. Gunneriusson, Terrorism and Cyber Attacks as Hybrid Threats: Defining a Comprehensive 21st Century Approach to Global Security, "The Journal on Terrorism and Security Analysis", spring 2014, p. 3.
} 
tions, allows Moscow to carry out an active campaign of rejection, aiming to mask its military intervention. Russian television is actively using militarist propaganda to mitigate and justify aggression.

It is worth noting the cyber-attack on Ukraine. Russia's actions against Ukraine are a good example of how cyber operations can be integrated into conventional military operations. Cyber-attack and anti-state propaganda campaigns of the Russian-Ukrainian conflict were carried out by DDoS attacks against Ukrainian media and government organizations, as well as on NATO and NGO sites. In addition, Russian communications intelligence used the data on the Internet to determine the location of the Ukrainian military units in eastern Ukraine.

Former NATO advisor on security issues, General Frank Van Kappen, was one of the Western analysts who described the Russian-Ukrainian conflict as a "hybrid war" on 26 April 2014.

It is possible to say that the "hybrid war" theory of the Russian-Ukraine conflict has been created. This type of war has already been recognized as "hybrid war" - one of the major challenges, confirming a new strategy against the threats by NATO in December 2015. As NATO Secretary General Jens Stoltenberg said at a meeting of the NATO Foreign Ministers in Brussels, the Alliance will agree with the EU in implementing a new strategy, as the hybrid war contains both military and civilian elements. The emergence of a hybrid war as a new form of conflict fundamentally alters the existing landscape and provides many questions about the possibilities of security systems ${ }^{10}$.

Finally, we can say that "Information War" is one of the most important threats of the XXI century, which threatens international security in addition to internal state relations. This can be used that support the recent history of the Russian Federation from the "information war" as the use of technology (2008) and Ukraine (2015-2016 years) against. Briefly, let's review the results of intelligence impact on the national security system of Georgia in the summer of 2008. Analysis of events allows us to assume that its northern neighbour used not only traditional ways of attack - by land, sea and air, but also implied the fourth, relatively new, but the most effective way of attack in terms of information, including cyber-space. According to the report published by the Ministry of Foreign Affairs of Georgia in August 2009, the Russian citizens and their sympathizers on 7-16 August 2008 carried out a coordinated attack that destroyed dozens of important web pages, including the web pages of the President, Defence Minister, National Bank of Georgia and other state agencies. Turns out, that cyber-

${ }^{10}$ A. Parulua, Hybrid Warfare - Contemporary Concept in Georgia's External Security, Tallinn 2018, p. 19. 
space protection (including the threat of a timely response to the propaganda) in terms of intelligence and counterintelligence measures completely collapsed.

The stability of national security depends much on each individual component of international security. One of the major and general components in the world today are considered the danger coming from asymmetric threats and hybrid war, which seriously threaten the national security and strategic interests of the states. The world faces a number of challenges that cannot be solved without a united effort. Therefore, with the purpose of prevention of similar threats and minimization of the risks, it is necessary for states to take appropriate steps toward cooperation, where collective security is granted with big significance and the necessity for forming alliances, increasing the effectiveness of international organizations, defending the international security system and protecting of global security occur. NATO plays an important role in tackling existing threats, has a strategic concept and takes preventive measures to combat threats. NATO has a variety of approaches, which are brought forward in its new conceptual documents, to ease the existing challenges and threats.

Security is especially important in the era of globalization, when economization, democratization, informatization creates unprecedented opportunities for development, but at the same time makes the international relations system more vulnerable against challenges such as terrorism, weapons of mass destruction to use.

\section{Conclusion}

The increasing popularity of the use of asymmetric threats and hybrid operations in more and more parts of conflict areas rise questions how to adopt traditional Western conventional warfare so that it is able to face new challenges of the $21^{\text {st }}$ century. The future conflicts will however no longer be possible to categorise only as conventional or irregular, state or non-state. NATO has mechanisms, means to combat actively asymmetric, and hybrid threats. The world is facing global threats, risks and challenges that make international security vulnerable with the development of new technologies. The development of technologies in the XXI century has brought many benefits to the society, but in terms of intelligence and "informational war" for its implementation, it has led to many threats. The security trends and new challenges play a major role in the establishment of a new system of international relations. After the Cold War, NATO's successful transformation and regulation of non-traditional security threats is the basic prerequisite for the globalization of the international role of the alliance. 
Asymmetric threats and hybrid warfare affect the global security environment, which makes the global security environment vulnerable to modern threats. Despite global changes in the world, NATO has managed to establish peace and stability in the Euro-Atlantic area. After the end of the Cold War, when the main enemy of the Warsaw military bloc was disintegrated, there was the illusion that NATO had exhausted its function and could have dissolved. NATO underwent a transformation in the post-Cold War period, which significantly strengthened the Alliance and helped stabilize the balance of the power in the world. Today, NATO successfully cope with new challenges and threats of the $21^{\text {st }}$ century and makes a significant contribution to the international security system.

\section{BIBLIOGRAPHY:}

$\checkmark$ Bachmann S. D., Gunneriusson H., Terrorism and Cyber Attacks as Hybrid Threats: Defining a Comprehensive 21st Century Approach to Global Security, "The Journal on Terrorism and Security Analysis", spring 2014

$\checkmark$ von Heinegg W. H., Asymmetric Warfare: How to Respond?, "International Law Studies", volume 87

$\checkmark$ Hoffman F. G., Hybrid Warfare and Challenges, "Joint Force Quarterly", Issue 52, 2009

$\checkmark$ Maghradze G., Maisaia V., 21st Century International Policy and Theory of Cooperative Security: Myth and Reality - Regional and Global Aspects, Tbilisi 2017

$\checkmark$ NATO Hybrid Threats. Background Report, Prague 2015

$\checkmark$ NATO's response to hybrid threats, <https://www.nato.int/cps/en/natohq/topics_156338.htm?selectedLocal $\mathrm{e}=\mathrm{en}>(30.06 .2018)$

$\checkmark$ Parulua A., Hybrid Warfare - Contemporary Concept in Georgia's External Security, Tallinn 2018

$\checkmark$ Secretary General to visit the Republic of Finland, $<$ https://www.nato.int/cps/en/natohq/news_147411.htm> (30.06.2018).

$\checkmark$ Strategic Concept For the Defence and Security of The Members of the North Atlantic Treaty Organization, 2011, <http://www.nato.int/lisbon2010/strategic-concept-2010-eng.pdf> (30.06.2018). 